\title{
Glutamic acid decarboxylase (GAD) autoantibodies are additional predictive markers of Type 1 (insulin-dependent) diabetes mellitus in high risk individuals
}

\author{
CH. Thivolet ${ }^{1}$, M. Tappaz ${ }^{2}$, A. Durand ${ }^{1}$, J.Petersen ${ }^{5}$, A.Stefanutti ${ }^{1}$, P.Chatelain ${ }^{4}$, B. Vialettes ${ }^{3}$, \\ W. Scherbaum ${ }^{6}$ and J. Orgiazzi ${ }^{1}$ \\ ${ }^{1}$ INSERM U197, Lyon, ${ }^{2}$ INSERM U171, Pierre-Bénite, ${ }^{3}$ Department of Internal Medicine, La Timone Hospital, Marseille, \\ ${ }^{4}$ Department of Pediatrics, Edouard Herriot Hospital, Lyon, France, ${ }^{5}$ Hagedorn Research Laboratories, Gentofte Denmark, \\ ${ }^{6}$ Department of Internal Medicine, University of Ulm, FRG
}

\begin{abstract}
Summary. The prevalence of glutamic acid decarboxylase autoantibodies was determined with an immunotrapping enzyme activity assay in newly-diagnosed Type 1 (insulin-dependent) diabetic patients as well as in first-degree relatives using rat brain homogenate as a source of glutamate decarboxylase. Twenty-six out of 86 islet-cell cytoplasmic autoantibody positive and one out of 24 islet cell autoantibody negative patients of recent onset, had autoantibodies to glutamate decarboxylase above the upper $99 \%$ confidence limit obtained from 89 control sera. Among 27 islet cell autoantibody positive relatives including 19 siblings and 8 parents, antibodies to glutamate decarboxylase were found in 8 of 9 $(89 \%)$ relatives and 7 of $8(87.5 \%)$ siblings with islet cell autoantibody titres above $20 \mathrm{JDF}$ units, in 1 of $19(5.2 \%)$ relatives with islet cell autoantibody titres between 2 and 5 JDF units, in 2 of $263(0.7 \%)$ siblings and 1 of 139 parents without islet cell autoantibodies. In first-degree relatives, high titre islet cell autoantibodies and autoantibodies to glutamate decar boxylase were tightly associated $\left(\mathrm{X}^{2}=182, p=0.0001\right)$. None of the relatives with low genetic risk $(n=64)$, i. e. HLA-different to the diabetic proband, was found to be antibody posi-
\end{abstract}

tive. Antibodies to glutamate decarboxylase were present only in those relatives sharing at least one haplotype with the diabetic proband, including two islet cell autoantibody negative but HLA-identical siblings. Autoantibodies to glutamate decarboxylase were present in 7 of $9(77 \%)$ relatives who developed the disease, including one islet cell autoantibody negative sibling. Altogether, the simultaneous presence of autoantibodies to glutamate decarboxylase and high titre islet cell autoantibody increases the positive predictive value for the disease from $66 \%$ to $75 \%$. This study indicates therefore that autoantibodies to glutamate decarboxylase detected by an immunotrapping enzyme activity assay are additional predictive markers for future development of Type 1 diabetes and should be now prospectively studied in high risk individuals as well as other autoantibodies to Beta-cell autoantigens.

Key words: Glutamate decarboxylase, Type 1 (insulin-dependent) diabetes mellitus, islet cell autoantibody, prediction.
The presence of autoimmune markers in high-risk individuals and newly-diagnosed Type 1 (insulin-dependent) diabetic patients, as well as experimental animal models where autoimmune effector T cells can cause Beta-cell destruction [1], strongly support the concept that Type 1 diabetes results from an immune mediated phenomenon in genetically susceptible individuals [2]. Evidence has accumulated that despite its acute onset, Type 1 diabetes is preceded by a long prodromal period during which Betacells are progressively destroyed. Family studies [3-6] have shown that the majority of those first-degree relatives who became diabetic had high titre islet-cell cytoplasmic autoantibodies (ICA) and insulin autoantibodies (IAA), months before diagnosis. However, only a fraction of ICA positive relatives progress to developing the disease, indicating that additional factors are required for the progression of Beta-cell destruction [6]. Identification of additional predictive markers in those individuals at very high risk for the disease would be of clinical importance, since recent immunointervention trials have indicated that if such treatment is to be effective it should be initiated at the early stages of the disease [7], at a time when the residual Beta-cell mass is sufficient to fulfill insulin needs. Glutamate decarboxylase (GAD), the enzyme that synthesizes GABA from glutamic acid, is the predominant autoantigen in a rare neurological syndrome known as stiff-man syndrome (SMS), in which almost all patients are also positive for ICA and some become diabetic [810]. Interestingly, the pancreatic islet Beta-cell autoantigen of relative molecular mass $64 \mathrm{kD}$, has been recently identified as GAD [11]. Pancreatic Beta cells as well as a subpopulation of central nervous system neurons 
express high levels of this enzyme. In this study, we used a specific immunotrapping enzyme activity (ITEA) assay to examine the prevalence and evolution of GAD autoantibodies in prediabetic individuals as well as in Type 1 diabetic patients of recent onset.

\section{Subjects and methods}

\section{Subjects}

A group of 110 recently-diagnosed Type 1 diabetic patients were tested for the presence of GAD antibodies including $86(78.2 \%)$ ICA positive patients. First-degree relatives were enrolled after informed consent that had been given for a screening programme for Type 1 diabetes which had been in progress since 1982. The characteristics of this family study referred to as the Lyons' family study have been previously published [4,6]. Between January 1982 and October 1991, circulating autoantibodies were analysed in 736 first-degree relatives, including 311 siblings 371 parents and 43 children of 241 Type 1 diabetic patients. Siblings had $1.65 \pm 1$ (mean \pm SD) blood samplesincluding $123(39.5 \%)$ with more than one blood sample. This latter group of relatives had a total of 342 samples which corresponded to a mean \pm SD number of samples per individual of $2.67 \pm 1.2$ for a mean \pm SD period of follow-up of $4.87 \pm 2$ years. Total follow-up of siblings represented 1202 person-years with a mean \pm SD observation period of $3.86 \pm 2.3$ years. During the time of study, 8 parents and 19 siblings showed islet cell antibodies (ICA). Eight siblings and one parent developed diabetes, including six individuals with high ICA titre. Two relatives who progressed to diabetes from the Marseille's family study were also included for retrospective evaluation of GAD antibodies. The control population consisted of 89 individuals aged $15 \pm 2$ years (mean $\pm S D)$.

\section{Detection of GAD autoantibodies with the ITEA assay}

Presence of GAD autoantibodies was sought for by an immunotrapping enzyme activity assay (ITEA) in which GAD activity was measured after immunofixation to serum immunoglobulins. Rat brain homogenate was used as a source of GAD. The brain homogenate from at least three animals was prepared in standard buffer, i.e. $50 \mathrm{mmol} / \mathrm{l} \mathrm{pH} 6.8$ sodium phosphate buffer containing $0.2 \mathrm{mmol} / \mathrm{l}$ pyridoxal phosphate (Sigma, St. Louis, Mo, USA) and $1 \mathrm{mmol} / \mathrm{l} \mathrm{ami-}$ noethylisothiouronium hydrobromide (Sigma), frozen and used for 50 antibody determinations in duplicate. Brain homogenate was incubated with protein A-sepharose on which serum IgGs had been preabsorbed. Briefly, $100 \mu \mathrm{l}$ of each serum sample were added to $100 \mu \mathrm{l}$ of protein A-sepharose (Pharmacia, Uppsala, Sweden) suspended ( $50 \%$ volume/volume, v/v) in phosphate buffered saline (PBS). After a 4-h incubation under constant agitation at $4^{\circ} \mathrm{C}$, samples were washed twice with $1 \mathrm{ml}$ of PBS, then in $1 \mathrm{ml}$ of standard buffer and $250 \mu \mathrm{l}$ of a $20,000 \mathrm{~g}$ supernatant from a $25 \%(\mathrm{w} / \mathrm{v})$ rat brain homogenate prepared in standard buffer were added. Following an overnight incubation at $4^{\circ} \mathrm{C}$ under constant shaking, samples were washed three times with $1 \mathrm{ml}$ of standard buffer, then divided into duplicate aliquots. Immunotrapped GAD was detected by measuringits enzymatic activity directly on the solid phase, using a radiometric assay according to Legay et al. [12]. Ten $\mu$ l of standard buffer containing $1 \mathrm{mmol} / 112.5 \mu \mathrm{Ci} / \mu \mathrm{mol} \mathrm{L}-1{ }^{-14} \mathrm{C}$ glutamic acid (CEA, Saclay, France) were added as substrate. The labelled carbon dioxide formed by GAD during a $1 \mathrm{~h} 30 \mathrm{~min}$ incubation at $37^{\circ} \mathrm{C}$ was trapped and measured as described previously [12]. Blanks were performed with protein-A sepharose only. A GAD antiserum raised in sheep [13] was used as a positive reference control.GAD activity immunotrapped by human sera was expressed in arbitrary units as the percentage of the GAD activity trapped by a positive reference control run in each set of assays under the same experimental conditions.
Several experiments were performed to standardize the ITEA assay. The ability of autoantibodies to bind GAD was tested using serial dilutions of anti-GAD positive or negative sera. In addition, the effect of increasing concentrations of brain homogenate was analysed. To demonstrate that immunotrapping of GAD was efficient, we re-reacted supernatants of an immunotrapped brain homogenate with the same immune serum used in the initial immunotrapping. To test the possibility that $64 \mathrm{kD}$ + /anti-GAD negative sera could contain blocking antibodies, we performed inhibition experiments where we first incubated $250 \mu \mathrm{l}$ of brain homogenate with $100 \mu \mathrm{l}$ of $64 \mathrm{kD}$ positive/GAD negative sera or a negative control serum for $4 \mathrm{~h}$ at $4^{\circ} \mathrm{C}$, then the immunotrapping assay was performed using $100 \mu \mathrm{l}$ of a positive control serum. Alternatively, to test the possibility that $64 \mathrm{kD}+$ /anti-GAD negative sera could bind to GAD and to the enzymatic site of the protein, we also immunoprecipitated brain homogenate previously incubated with the corresponding antibodies prior to the immunotrapping assay.

To compare the sensitivity of the ITEA assay to that of the $64 \mathrm{kD}$ immunoprecipitation technique, we analysed in parallel serial dilutions of a positive serum using the two techniques. In this particular experiment, we quantitated the effects of serum dilution on the level of anti-64 kD antibodies. Relative amounts of precipitated antigens were determined by densitometric scanning of the fluorographs and expressed as a percentage of the initial serum dilution.

\section{Detection of $64 k D$ autoantibodies by immunoprecipitation}

Immunoprecipitations of the $64 \mathrm{kD}$ antigen were performed using highly purified neonatal rat islets which were synthetically labelled with ${ }^{35} \mathrm{~S}$-methionine, homogenized and ultracentrifuged $(100,000 \mathrm{~g}$ for $1 \mathrm{~h}$ at $4^{\circ} \mathrm{C}$ ) after the removal of cell debris (1000 g, $\left.10 \mathrm{~min}\right)$. The cytosolic fraction was diluted in 1\% Triton-X 114 (Sigma Laboratories, Grand Island, NY, USA) $(1 / 10, \mathrm{v} / \mathrm{v})$, heated at $37^{\circ} \mathrm{C}$ for $2 \mathrm{~min}$ to induce phase separation. The detergent phase was then immunoprecipitated with test sera diluted 1:4 using protein A sepharose (Pharmacia Fine Chemical, Uppsala, Sweden) and the immunoprecipitated $64 \mathrm{kD}$ antigen was identified using $10 \%$ sodium dodecyl sulphate-polyacrylamide gel electrophoresis (SDS-PAGE) under reducing conditions and fluorography, as previously described [16]. The amount of protein extract per lane corresponded to 550 islets. The precipitated $64 \mathrm{kD}$ antigens can be often separated into three different bands which correspond to different GAD isoforms [17].

\section{Detection of islet cell autoantibodies (ICA)}

Four micron sections of frozen pancreas from a human cadaver of blood group $\mathrm{O}$ were used as substrates for ICA determination by indirect immunofluorescence. The end point titres causing detectable fluorescence were converted into Juvenile Diabetes Foundation (JDF) units. Our laboratory participated in ICA proficiency tests and in the 4th JDF sponsored International Diabetes Workshop and our average results from three different tests were $90 \%$ for validity, $95 \%$ for consistency, $95 \%$ for specificity, and $80 \%$ for sensitivity.

Genetic determination was performed in $92 \%$ of the relatives by serological methods using reference sera and by oligonucleotide typing for the study of DQ- $\beta$ chain sequence polymorphism at position 57 (Blood Transfusion Centre, Lyon, France) according to the 10th International Workshop. Analysis of ICA and GAD autoantibodies were conducted in 250 siblings according to the level of HLA identity.

\section{Statistical analysis}

Statistical comparisons between entry and the latest follow-up were made using the paired $t$-test. Comparison of ICA titre between groups of relatives was performed using the Mann-Whitney U-test. 


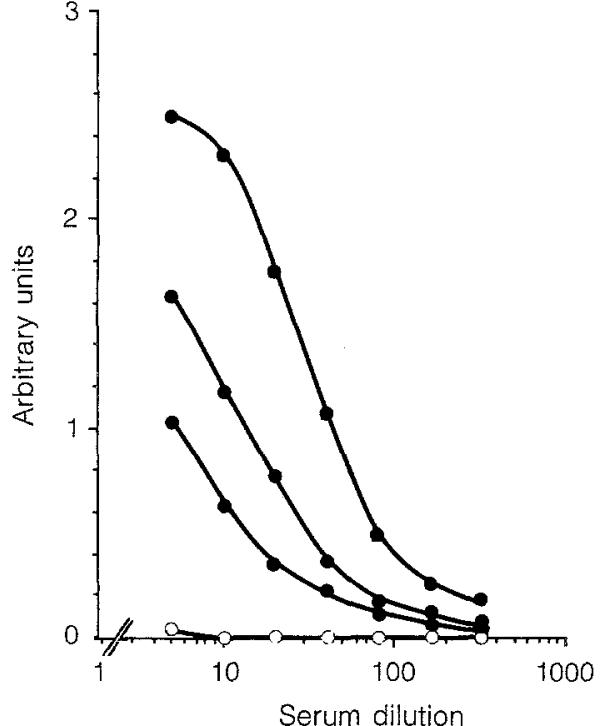

Fig.1. Dilution curves of three sera containing autoantibodies to glutamate decarboxylase (GAD) (closed circles) and one $64 \mathrm{kD}$ positive-GAD (ITEA) negative serum (open circle). Normal 99\% confidence interval of normal values is $0-0.11$ units

$2 \times 2$ contingency tables and Chi-square analysis were performed to compare relationship of DR alleles and GAD antibodies. Results are expressed as mean $\pm \mathrm{SD}$.

\section{Results}

\section{Precision, specificity and sensitivity of the GAD/ITEA assay}

The variation of GAD content of a frozen brain homogenate over a 1-month period did not exceed $6 \%$ and the variation in GAD content of ten different homogenates was less than $18 \%$. The inter-assay coefficient of variation based on eight assays performed independently, was less than $17 \%$ for three positive samples with different levels of positivity. The mean \pm SD of 89 normal sera was $0.04 \pm 0.03$ units. The upper $99 \%$ confidence limit was 0.11 units, which was taken as cut-off for positivity.

Dilution curves of three GAD autoantibody-positive sera and one $64 \mathrm{kD}$ positive-GAD antibody negative serum are presented in Figure 1. The loss of signal was noticed between 1:80 and 1:160. The level of GAD antibodies obtained by incubating graded quantities of rat brain homogenate was studied. Increasing concentrations of rat brain homogenate from 250 to $500 \mu \mathrm{l}$ increased the specific binding by $20 \%$. Concentrations above $500 \mu \mathrm{l}$ increased the non-specific binding of negative sera which however remained within normal range. To test the efficiency of a positive serum to bind to brain GAD, we re-reacted supernatants of an immunotrapped brain homogenate with the same immune serum. The amount of immunotrapped GAD during the second assay, corresponded to only $14 \%$ of the initial value trapped during the first assay.

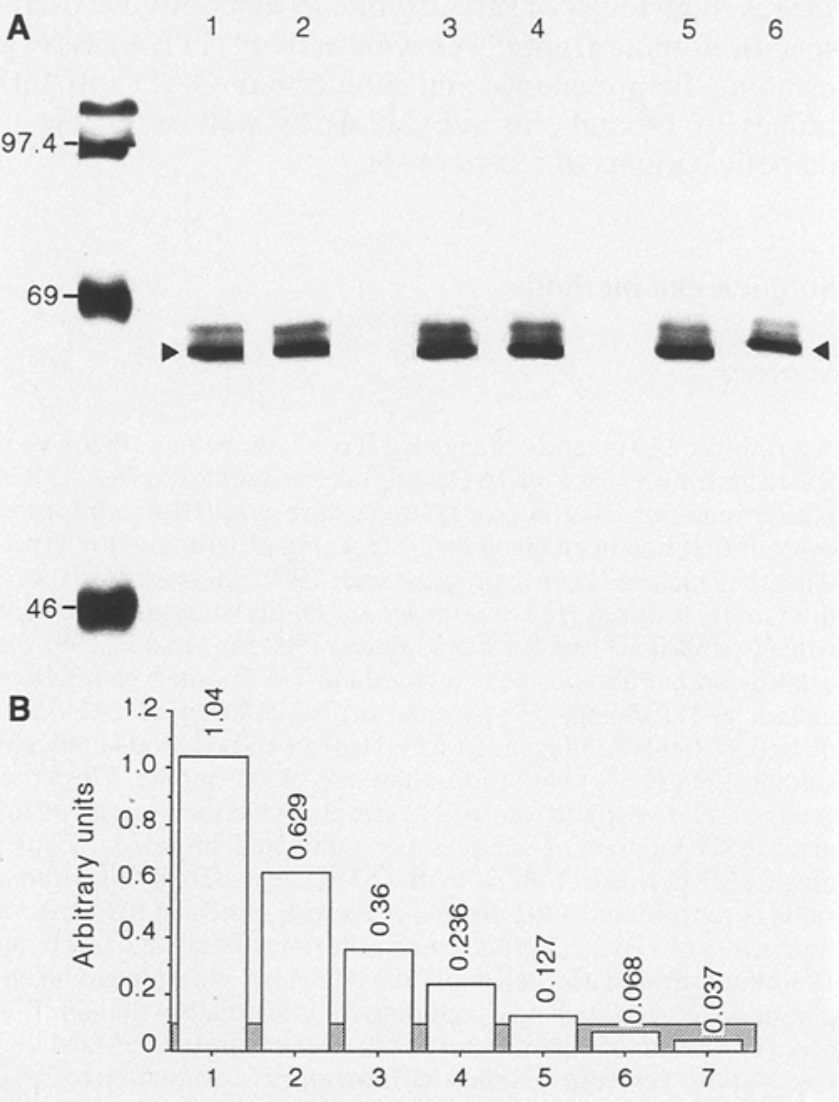

Fig. 2. Panel A describes $64 \mathrm{kD}$ antibody levels using immunoprecipitation of rat islet extracts during serial dilutions (lanes 1 to $6: 1: 4$, $1: 8,1: 16,1: 32,1: 128,1: 256)$. The upper band corresponds to GAD 67. GAD 64 is divided into GAD $64 \beta$ which corresponds to the lower band on the gel and GAD $64 \alpha$ which is represented by the weak band between GAD 67 and GAD 64ß. Panel B shows the autoantibodies to glutamate decarboxylase (GAD) of the same serum, using the immunotrapping enzyme activity assay (ITEA) (lanes 1 to $7,1: 5,1: 10,1: 20,1: 40,1: 80,1: 160,1: 320$ ). The shaded area represents the $99 \%$ confidence interval of normal values

Comparison of sensitivity between ITEA and $64 \mathrm{kD}$ immunoprecipitation assays was performed with serial dilutions of a reference serum tested in parallel using both techniques. Results presented in Figure 2 revealed that in the ITEA assay the loss of positivity occurred after a dilution of 1:80, whereas the end-point dilution using the immunoprecipitation technique was 1:1000. Densitometric scanning of precipitated antigens during the $64 \mathrm{kD}$ assay measured the effects of serum dilution showing a $38 \%$ decrease in the intensity of the three bands of the $64 \mathrm{kD}$ antigen at a dilution of $1: 256$ when compared to $1: 4$, with a differential effect on the upper band corresponding to GAD 67 which decreased to $47 \%$ of the initial intensity. In this particular experiment, $64 \mathrm{kD}$ immunoprecipitation was therefore 10-15 times more sensitive than the ITEA assay to detect $\mathrm{GAD} / 64 \mathrm{kD}$ autoantibodies.

In order to study whether antibodies directed to the enzymatic site of GAD could be present in GAD (ITEA) negative sera, we performed additional sets of experiments. Aliquots of brain homogenates were pre-incu- 
Table 1. Prevalence of islet-cell cytoplasmic autoantibodies (ICA) and autoantibodies to glutamate decarboxylase (GAD) in newlydiagnosed Type 1 (insulin-dependent) diabetic patients and firstdegree relatives

\begin{tabular}{lrlll}
\hline Subject group & $n$ & $\begin{array}{l}\text { ICA } \\
n(\%)\end{array}$ & $\begin{array}{l}\text { GAD } \\
n(\%)\end{array}$ & $\begin{array}{l}\text { Type 1 diabetes } \\
n(\%)\end{array}$ \\
\hline Patients & 110 & $86(78)$ & $27(24.5)$ & $110(100)$ \\
ICA + & 86 & $86(100)$ & $26(30.2)$ & \\
Siblings & 282 & $19(6.7)$ & $9(3.2)$ & $8(2.8)^{\mathrm{a}}$ \\
ICA + & 19 & $19(100)$ & $7(37)$ & $6(31.5)$ \\
ICA > 20 JDF & 8 & $8(100)$ & $7(87.5)$ & $5(62.5)$ \\
ICA - & 263 & $0(0)$ & $2(0.7)$ & $2(0.7)$ \\
Parents & 371 & $8(2.1)$ & $3 / 147$ & $1(0.3)^{\mathrm{a}}$ \\
ICA + & 8 & $8(100)$ & $2(25)$ & $1(12.5)$ \\
ICA > 20 JDF & 1 & $1(100)$ & $1(100)$ & $1(100)$ \\
Control subjects & 89 & $0(0)$ & $0(0)$ & $0(0)$ \\
\hline
\end{tabular}

${ }^{a}$ Relatives who became diabetic during follow-up

Table 2. Prevalence of autoantibodies to glutamate decarboxylase (GAD) and HLA phenotypes in newly-diagnosed Type 1 (insulindependent) diabetic patients and siblings

\begin{tabular}{lrll}
\hline Study group & $n$ & ICA (\%) & GAD (\%) \\
\hline Patients & & & \\
DR3 & 40 & $24(60)$ & $6(15)$ \\
DR4 & 23 & $18(78.2)$ & $4(17.4)$ \\
DR3/4 & 21 & $13(62)$ & $4(19)$ \\
DRX/X & 7 & $4(57)$ & $2(28.6)$ \\
Siblings & & & \\
HLA identical & 72 & $4(5.5)$ & $5(6.9)$ \\
HLA haploidentical & 114 & $7(6.1)$ & $4(3.5)$ \\
HLA different & 64 & $0(0)$ & $0(0)$ \\
\hline
\end{tabular}

bated with six $64 \mathrm{kD}$ positive/GAD (ITEA) negative sera before the detection of GAD autoantibodies in a positive reference serum using the ITEA assay. No significant difference was noticed in the level of GAD antibodies from a positive control serum by pre-incubating the brain homogenate with six different sera giving a mean (range) coefficient of variation of $8.3(17.2) \%$. In addition, $64 \mathrm{kD}$ positive/anti-GAD negative sera did not bind significant amounts of the protein, since the amount of GAD detected by a positive control serum was not influenced after preincubating and immunoprecipitating brain homogenate using these particular sera prior to the assay procedure.

\section{Prevalence of GAD antibodies in Type 1 diabetic patients of recent onset and first-degree relatives}

Sera from 110 recently-diagnosed Type 1 diabetic patients were studied for the presence of GAD autoantibodies within 1 month of treatment including $89(78 \%)$ ICA-positive individuals. The ITEA assay revealed in 27 of them $(24.5 \%)$ the presence GAD antibody levels above the $99 \%$ upper confidence interval limit (Table 1). All but one were ICA positive. Age at onset $(10.4 \pm 2$ vs $8.4 \pm 4$ years, $p=0.24)$ and duration of disease $(0.9 \pm 2 \mathrm{vs}$ $0.7 \pm 0.6$ months, $p=0.1$ ) did not influence the presence of
GAD antibody. Using $2 \times 2$ contingency tables, no significant difference was observed in the distribution of DR3 $\left.\left(\mathrm{X}^{2}=0.009\right), p=0.9\right)$ and/or DR4 alleles $\left(\mathrm{X}^{2}=0.38\right.$, $p=0.8$ ) between patients according to positivity for GAD autoantibodies (Table 2).

Among 27 ICA-positive relatives studied, 9 (33\%) had also GAD autoantibodies, and this association was clearly significant $\left(\mathrm{X}^{2}=71, p=0.0001\right)$. GAD autoantibodies were strongly associated with high titre ICA $\left(\mathrm{X}^{2}=182\right.$, $p=0.0001)$, since seven out of eight (87.5\%) siblings with ICA titres above 20 JDF units were GAD autoantibody positive. However, two ICA negative siblings and one of 139 ICA negative parents also had GAD antibodies (Table 1). In addition, 1 of 19 relatives with ICA titres between 2 and 5 JDF units had also GAD autoantibodies. All GAD autoantibody positive relatives shared at least one haplotype with the diabetic proband (Table 3). Moreover, two other ICA-positive relatives who progressed to diabetes in the Marseille's prospective family study were also found to be GAD (ITEA) autoantibody positive before onset. The positive predictive value of high titre ICA was slightly higher than that of GAD antibodies, but the simultaneous presence of both markers increased the predictive value to $75 \%$. Five GAD autoantibody positive relatives did not develop the disease (Table 3). Among them, two had high titre ICA, including one HLA identical and one HLA-haploidentical siblings. One parent had low ICA titres at two different controls during 5 years of follow-up and another parent was ICA negative at one occasion. The last relative among the five, was an HLAidentical sibling (number 9) who was ICA negative and had high levels of GAD antibodies. For this subject, the follow-up period was too short to conclude on the metabolic outcome.

Of the 12 relatives who presented GAD (ITEA) autoantibodies, seven developed the disease. The evolution of GAD antibody levels in serial samples of nine ICA-positive relatives before diabetes onset (seven from the Lyons' family study and two from the Marseille's family study) is presented in Figure 3. Six relatives were HLA haploidentical and three HLA-identical to their diabetic proband. All had at least one serum sample with ICA above $20 \mathrm{JDF}$ units. Ages ranged from 11 to 43 years (median 20.8 years) and duration of discordance was from 2 to 34 years (median 11.8 years). Seven out of these nine relatives who progressed to diabetes had GAD autoantibodies. This gave to the GAD (ITEA) assay a sensitivity of $77.7 \%$, a specificity of $98.8 \%$ and a positive predictive value of $63.6 \%$ (Table 4 ).

\section{Discussion}

Although strong experimental evidence supports the concept that Type 1 diabetes is a T-cell mediated disease, serological markers are the best indicators of the ongoing autoimmune process in genetically susceptible individuals. Here, we used a specific ITEA assay to detect GAD autoantibodies at onset as well as in first degree relatives, in addition to other established serological markers. GAD autoantibodies were found in $24.5 \%$ of recently-diag- 
Table 3. Characteristics of 12 relatives with autoantibodies to glutamate decarboxylase (GAD)

\begin{tabular}{|c|c|c|c|c|c|c|}
\hline Relative & Age at entry & $\begin{array}{l}\text { Follow-up } \\
\text { (years) }\end{array}$ & HLA identity & ICA (JDF units) & $\begin{array}{l}\text { Peak value of GAD } \\
\text { antibodies (units) }\end{array}$ & Outcome \\
\hline 1 & 6 & 5 & Identity & 20 & 0.7 & Diabetic \\
\hline 2 & 15 & 4.5 & $1 / 2$ identity & 80 & 0.31 & Diabetic \\
\hline 4 & 9 & 5 & Identity & 80 & 0.49 & Diabetic \\
\hline 5 & 41 & 4 & $1 / 2$ identity & 320 & 0.26 & Diabetic \\
\hline 6 & 9 & 7 & $1 / 2$ identity & 80 & 0.13 & Diabetic \\
\hline 9 & 19 & 0.5 & Identity & 0 & 0.54 & Normal \\
\hline 10 & 8 & 2 & $1 / 2$ identity & 80 & 0.21 & Normal \\
\hline 11 & 10 & 8 & $1 / 2$ identity & 160 & 0.26 & Normal \\
\hline 12 & 23 & 0.9 & $1 / 2$ identity & 0 & 1.3 & Normal \\
\hline
\end{tabular}

a The $99 \%$ confidence interval of normal values is $0-0.11$

Table 4. Predictive values of high islet cell autoantibody (ICA) titre and autoantibodies to glutamate decarboxylase (GAD) in first degree relatives

\begin{tabular}{lcll}
\hline Serological marker & $\begin{array}{l}\text { Number } \\
\text { of relatives }\end{array}$ & $\begin{array}{l}\text { Number } \\
\text { who became } \\
\text { diabetic }\end{array}$ & $\begin{array}{l}\text { Positive } \\
\text { predictive } \\
\text { value (\%) }\end{array}$ \\
\hline ICA & 27 & 7 & 26 \\
ICA > 20 JDF units & 9 & 6 & 66 \\
GAD antibodies & $11^{\text {a }}$ & 7 & 63.6 \\
ICA $>$ 20 JDF units and & 8 & 6 & 75 \\
GAD antibodies & & & \\
\hline
\end{tabular}

a This number excludes relative number 9 who had a very short period of follow-up

nosed Type 1 diabetic patients and predominantly in those with ICA (30.2\%). No genetic combination distinguished patients with or without GAD autoantibody at onset. Interestingly, all but one prediabetic individuals with high titre ICA had also GAD autoantibodies. None of the individuals with low risk of diabetes -i.e. HLA-different siblings (Table 2) and ICA negative control subjects - presented GAD autoantibodies. This gave to the presence of GAD autoantibodies during prediabetes a high positive predictive value for disease onset but combining GAD antoantibodies and ICA gave an even higher predictive value. Sequential analysis of anti-GAD activity detected in prediabetic individuals before diabetes onset showed high levels of this marker independent from the fluctuations of ICA titres. The observation of one ICA positive but GAD autoantibody negative sibling and of one ICA and GAD autoantibody negative sibling who became diabetic during follow-up, further supports the concept of immunological heterogeneity during prediabetes [6].

Clinical observations of SMS patients with Type 1 diabetes $[9,10]$ is intriguing, with presence of autoantibodies to both GABAergic neurons and Beta cells [11]. GAD, the dominant autoantigen in SMS, is the GABA synthesizing enzyme in Purkinje cells. In keeping with biochemical and functional similarities between neurons and peptide-secreting endocrine cells, GAD is also present in high concentrations in pancreatic Beta-cells as indicated by immunohistochemical studies $[12,13]$. This enzyme has been located at the cytoplasmic surface of synaptic-like microvesicles [14]. Beta-cell GAD is biochemically indistinguishable from brain GAD. Cloning and partial nucleotide sequencing of human GAD cDNA from human brain and human pancreatic islets revealed an overall homology of $92 \%$ [15]. These considerations have lead to the hypothesis that GAD autoimmunity in SMS and Type 1 diabetes might be interrelated.

The recent demonstration $[16,17]$ that GAD was comparable to the $64 \mathrm{kD}$ protein immunoprecipitated by patients' sera from extracts of human islets [18], has brought considerable interest in the quest of the putative target(s) antigen(s) involved in Type 1 diabetes. Previous studies using human $[19,20]$ or non-obese diabetes (NOD) mouse sera [21], suggested that the $64 \mathrm{kD}$ protein was specifically precipitated from crude islet cell extracts and purified membrane protein fraction during the prediabetic phase. However, $64 \mathrm{kD}$ autoantibodies did not correlate with other serological markers such as ICA. Our aim was to develop an assay that could be used to screen large numbers

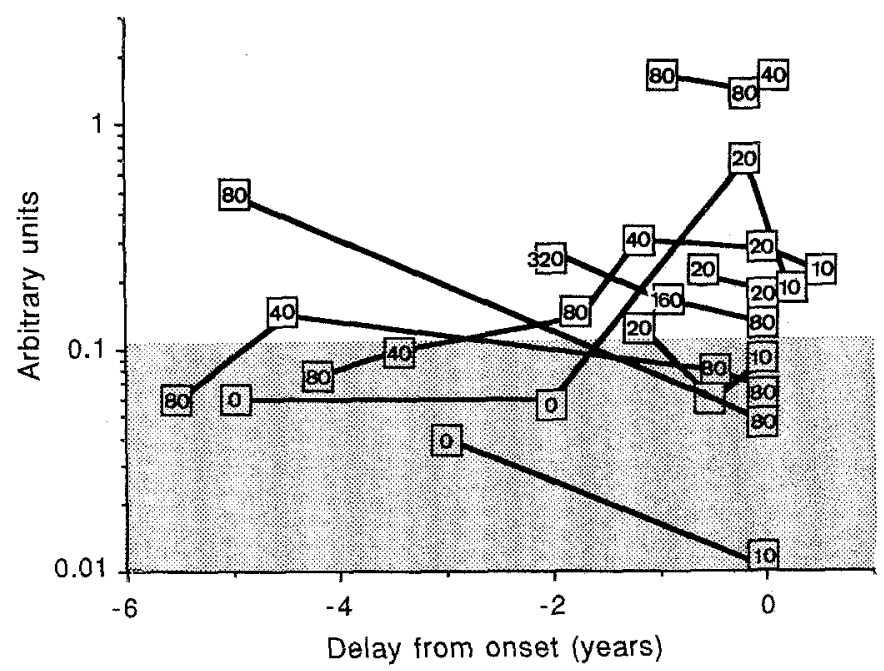

Fig.3. Evolution of autoantibodies to glutamate decarboxylase (GAD) before onset of diabetes in nine islet-cell cytoplasmic autoantibody (ICA) positive first-degree relatives of Type 1 (insulindependent) diabetic patients. ICA titres of each sample are given in JDF units. The shaded area represents the $99 \%$ confidence interval of normal values 
of high risk individuals for the presence of GAD autoantibodies during prediabetes. Although a discordance in prevalence of GAD (ITEA) and GAD/64 kD autoantibodies was noticed in newly-diagnosed patients, the frequency of antibodies to GAD detected by the ITEA assay during prediabetes was comparable to what has been published for the prevalence of $64 \mathrm{kD}$ antibodies [19, 20].

We analysed several possibilities to explain the apparent discrepancy between the two assay systems. They are different in sensitivity. The $64 \mathrm{kD}$ immunoprecipitation procedure was 10-15 times more sensitive than the ITEA assay which may therefore only identify the highly positive sera. However, we have not been able on a limited number of sera to find any correlation between the intensity of the precipitated $64 \mathrm{kD}$ antigens and the levels of antibodies to GAD during the ITEA assay. However, it must be emphasized that this difference in sensitivity did not influence the predictive value of GAD (ITEA) autoantibodies, since the majority of relatives who subsequently became diabetic were found positive in our assay.

Another explanation could be that some individuals may have antibodies to the enzymatic site of the protein which could hinder the detection in the ITEA assay. However, preincubation of brain homogenate with GAD/64 kD positive-GAD (ITEA) negative sera did not influence further detection of GAD (ITEA) autoantibodies present in a reference serum. In addition, at no point did serial dilutions of these GAD (ITEA) negative sera uncover any secondary anti-GAD activity, an observation against the existence of blocking antibodies. Although we cannot conclude definitively on this matter, the problem of blocking antibodies does not appear crucial.

Limitations due to tissue and species specificity of these antibodies can be also excluded, since GAD is highly conserved in mammals. A large sequence homology was recently demonstrated between brain and Beta-cell GAD cDNAs [15]. The two forms of rat brain GAD namely $\mathrm{GAD}_{65}$ and $\mathrm{GAD}_{67}$ [21] which differ in size, amino acid sequence and function, and are encoded by two distinct genes [23], are recognized by patients' sera [24]. Preincubation of a positive serum with rat brain GAD or recombinant rat brain $\mathrm{GAD}_{65}$ was shown to inhibit the immunoprecipitation of the $64 \mathrm{kD} / \mathrm{GAD}$ antigen from human islet extracts $[18,23]$.

Different patterns of epitope recognition may be also present among individuals. Extraction of islet cells with non-anionic detergents prior to immunoprecipitation may reveal hidden immunoreactive sites. This hypothesis can apply to the recent identification by Christie et al. [25], of autoantibodies to tryptic fragments of the whole molecules. Therefore, GAD and the $64 \mathrm{kD}$-antigen may share a large number of epitopes without being fully identical.

In conclusion, our ITEA assay system of detecting GAD autoantibodies is a useful tool to monitor large numbers of individuals at high risk of developing Type 1 diabetes. In addition, this system allows quantification of anti-GAD autoantibodies. Further studies are needed to understand the pathophysiological role of such autoantibodies.
Acknowledgements. Members of the Lyons' family study also included Professors F.Berthezène, R. François, R. Mornex, J. Tourniaire. We thank Drs. L. Gebuhrer and H. Betuel for HLA determination. This work was supported by the French Medical Research Institute (INSERM, Réseau Clinique $\mathrm{n}^{\circ} 488015$ ), the Scientific Council of the Region Rhône-Alpes and by a French Diabetic Association (ALFEDIAM)-Novo Nordisk research grant.

\section{References}

1. Castano L, Eisenbarth GS (1990) Type 1 diabetes: a chronic autoimmune disease of human, mouse and rat. Ann Rev Immunol 8: 647-679

2. Todd JA (1990) Genetic control of autoimmunity in Type 1 diabetes. Immunol Today 11: 122-129

3. Tarn AC, Thomas JM, Dean BM et al. (1988) Predicting insulin dependent diabetes. Lancet I: 845-850

4. Thivolet CH, Beaufrère B, Betuel Het al. (1988) Islet cell and insulin autoantibodies in individuals at high risk of development of Type 1 (insulin-dependent) diabetes mellitus: the Lyon's family study. Diabetologia 31:741-746

5. Bonifacio E, Bingley PJ, Shattock M et al. (1990) Quantification of islet-cell antibodies and prediction of insulin-dependent diabetes. Lancet I 335: 147-149

6. Thivolet CH, Beaufrère B, Geburher L et al. (1991) Autoantibodies and genetic factors associated with development of Type 1 (insulin-dependent) diabetes mellitus in first degree relatives of diabetic patients. Diabetologia 34: 186-191

7. Bougnères PF, Carel JC, Castano L et al. (1988) Factors associated with early remission of Type 1 diabetes in children treated with cyclosporine. N Engl J Med 318: 663-670

8. Oertel WH, Schmechel DE, Tappaz ML, Kopin IJ (1981) Production of a specific antiserum to rat brain glutamic acid decarboxylase by injection of an antigen-antibody complex. Neuroscience 6: 2689-2700

9. Solimena M, Folli F, Denis-Domini S, Comi GC, Pozza G (1988) Autoantibodies to Glutamic Acid Decarboxylase in a patient with Stiff-man syndrome, epilepsy, and Type 1 diabetes mellitus. N Engl J Med 318: 1012-1020

10. Williams AC, Nutt JG, Hare T (1988) Autoimmunity in stiff-man syndrome. Lancet II: 222

11. Solimena M, Folli F, Aparasi R, Pozza G, De Camilli P (1990) Autoantibodies to Gaba-ergic neurons and pancreatic beta cells in stiff-man syndrome. N Engl J Med 322: 1555-1560

12. Vincent SR, Hökfelt T, Wu JY, Elde RP, Morgan LM, Kimmel JR (1983) Immunohistochemical studies of the GABA system in the pancreas. Neuroendocrinology 36: 197-204

13. Okada Y, Hosoya Y, Taniguchi H (1976) High concentration of GABA and high glutamate decarboxylase activity in rat pancreatic islets and human insulinoma. Science 194: 620-622

14. Reetz A, Solimena M, Matteoli M, Takei K, De Camilli P (1991) GABA and pancreatic $\beta$ cells: colocalization of Glutamic acid Decarboxylase (GAD) and GABA with synaptic-like microvesicles suggests their role in GABA storage and secretion. EMBO J 10: 1275-1284

15. Cram DS, Barnett LD, Joseph JL, Harrison LC (1991) Cloning and partial nucleotide sequence of human Glutamic Acid Decarboxylase cDNA from brain and pancreatic islets. Biochem Biophys Res Commun 176: 1239-1244

16. Baekkeskov S, Aanstoot HH, Christgau S et al. (1990) Identification of the $64 \mathrm{kD}$ autoantigen in insulin-dependent diabetes as the GABA-synthesizing enzyme glutamic acid decarboxylase. Nature 347: 151-156

17. Michelsen BK, Petersen JS, Boel E, Moldrup A, Dyrberg T, Madsen OD (1991) Cloning, characterization and autoimmune recognition of rat islet glutamic acid decarboxylase in insulindependent diabetes mellitus. Proc Natl Acad Sci USA 88: 8754 8758

18. Baekkeskov S, Nielsen JH, Marner B, Bilde T, Ludvigsson J, Lernmark A (1982) Autoantibodies in newly-diagnosed diabetic 
children immunoprecipitate specific human pancreatic islet cell proteins. Nature 298: 167-169

19. Baekkeskov S, Landin M, Kristensen JK et al. (1987) Antibodies to a $\mathrm{Mr} 64.000$ human islet cell antigen precede the clinical onset of diabetes. J Clin Invest 79: 926-934

20. Atkinson MA, MacLaren N, Sharp D, Lacy PE, Riley WJ (1990) $64,000 \mathrm{M}$ autoantibodies as predictors of insulin-dependent diabetes. Lancet II: $1357-1360$

21. Atkinson MA, Maclaren NK (1988) Autoantibodies in nonobese diabetic mice immunoprecipitate $64.000-\mathrm{Mr}$ islet antigen. Diabetes 37: 1587-1590

22. Legay F, Henry S, Tappaz M (1987) Evidence of two distinct forms of native glutamic acid decarboxylase in rat brain soluble extract: an immunoblotting study. J Neurochem 48: 1022-1026

23. Erlander MG, Tillakaratna NJ, Feldblum S, Patel N, Tobin AJ (1991) Two genes encode distinct glutamate decarboxylase. Neuron 7:91-100
24. Kaufman DL, Erlander MG, Clare-Salzer M, Atkinson MA, MacLaren NK, Tobin AJ (1992) Autoimmunity to two forms of glutamate decarboxylase in insulin-dependent diabetes mellitus. Proc Natl Acad Sci USA 89: 283-292

25. Christie MR, Vohra G, Champagne P, Daneman D, Delovitch TL (1990) Distinct antibody specificities to a $64 \mathrm{kD}$ islet cell antigen in Type 1 diabetes as revealed by trypsin treatment. J Exp Med 172: 789-794

Received: 11 November 1991

and in revised form: 3 February 1992

Dr. CH. Thivolet

INSERM U197

Faculté Alexis Carrel

Rue Guillaume Paradin

F-69008 Lyon, France 